\title{
ZÁHONY SZEREPE AZ EURÓPA ÉS ÁZSIA KÖZTI VASÚTI ÁRUSZÁLLÍTÁSBAN
}

\author{
(The Role of Záhony in the Rail Freight Transport \\ between Europe and Asia)
}

\author{
IMRE GABRIELLA
}

\begin{abstract}
Kulcsszavak:
Záhony vasúti áruszállitás Európa és Ázsia közti szárazföldi közlekedési folyosók

A tanulmány bemutatja a záhonyi átrakó körzet jelenlegi szerepét a kelet-nyugati irányú vasúti áruszállítási kapcsolatokban. Mivel Záhony stratégiai pozíciójának megértése szélesebb kitekintést igényel, áttekintést nyújtunk az Európa és Ázsia közti föbb közlekedési útvonalakról és bemutatjuk a vasúti áruszállitás jelentöségét az EU-FÁK-térség és EU-Kina közötti kereskedelmi kapcsolatokban.
\end{abstract}

A záhonyi térség társadalmi-gazdasági profilja az elmúlt évtizedek során egyértelmủen az áruszállításhoz, ezen belül is kiemelten a vasúti áruszállításhoz kapcsolódott. A rendszerváltás után a külkapcsolatokban bekövetkezett orientációváltás Záhony áruszállitásban betöltött szerepének csökkenését eredményezte, napjainkban azonban $a z$ Európa és Ázsia közötti kereskedelem dinamikus bővülése, valamint a magyarukrán határtérség új geopolitikai helyzete a logisztikai szerepkör újra felértékelődéséhez vezethet. Egy nemzetközi árufuvarozási tanulmány Záhony vasúti forgalmára (a szlovákiai Ágcsernyővel együtt) 2020-ig 80-150\%-os növekedést jelzett, amely elsősorban a megnövekedett kínai és orosz áruszállításokból fakadhat (Ad Toet 2005) ${ }^{1}$.

A záhonyi térség speciális adottságainak kihasználása, a tranzitforgalom és Magyarország nemzetközi logisztikai szerepének növelése érdekében elkészült a záhonyi térség komplex gazdaságfejlesztési programja, amely infrastruktúrafejlesztéssel és az áruforgalom kiszolgálására alkalmas korszerü logisztikai és feldolgozóipari kapacitások megteremtésével kívánja előmozdítani az elmaradott magyarukrán határtérség felzárkózását és az eddigieknél hatékonyabb bekapcsolódását a kelet-nyugati irányú vasúti áruforgalomba ${ }^{2}$.

A tanulmány fő kérdése, hogy a megnövekedett kínai és orosz áruszállítási igények milyen perspektívákat jelenthetnek Záhony számára, létrejöhet-e (és ha igen, milyen feltételek mellett) a prognosztizált forgalomnövekedés. A tanulmány első része bemutatja az Európa és Ázsia közti föbb közlekedési útvonalakat, különös tekintettel a 2000 szeptemberében hivatalosan is kijelölt szárazföldi közlekedési folyosókra, és megvizsgálja ezen útvonalak versenyképességét egymáshoz, illetve a tengeri szállitási módhoz képest, majd az EU és Kína, illetve az EU és a FÁK-térség közti kereskedelmi kapcsolatok általános tendenciáit ismerteti és a fenti relációkban megvizsgálja a vasúti szállítás jelentőségét. Végül bemutatja, hogyan alakult a záhonyi térség kelet-nyugati vasúti áruforgalomban betöltött szerepe az ezredforduló 
után, tekintettel a különböző közép-kelet-európai átrakó-központok (a lengyel határon Malaszewicze, illetve különös hangsúllyal a szlovákiai Čierna nad Tisou) között kialakult versenyből fakadó kockázatokra.

\section{Az Európa és Ázsia közti közlekedési folyosók}

\section{Tengeri útvonalak}

Összesen hét, általánosan elfogadott közlekedési folyosó létezik Európa és Ázsia között, ebböl három tengeri útvonal, négy pedig szárazföldi szállítási folyosó. A tengeri útvonalak közül a legdélebbi folyosó átszel három óceánt, és délről (a Jóreménység-foknál) megkerüli Afrikát. Előnye, hogy korlátozás nélkül, bármekkora hajók közlekedésére alkalmas; viszont ez egyben a leghosszabb útvonal is, a szállítási idő akár az 50 napot is elérheti. Ennél 1600 km-rel rövidebb a Szuezicsatornán át vezető tengeri út, ezen azonban - a csatorna folyamatos bővítése ellenére komoly korlátozások vannak érvényben a hajók méretét és számát illetően. Ezt a folyosót használva ugyan 28-32 napra rövidül az ázsiai kikötőkből Európába tartó út időtartama, azonban a kikötési és a berakodási idővel együtt a szállítás még így is 45 napot vehet igénybe. A harmadik folyosó, amely a Jeges-tenger partvidéke mentén, Ázsiát észak felől megkerülve éri el Észak-Európát, jelenleg pusztán elméleti lehetőség a két kontinens tengeri úton történő összekapcsolására. Ez az útvonal ugyan 7200 km-rel rövidebb a Szuezi-csatornát átszelő útnál, azonban a közeljövőben kevésbé lehet jelentős, mivel egyrészt szegényes infrastuktúrával rendelkező kikötők szegélyezik, másrészt csak jégtörő hajókkal járható (Erdősi 2007; Fleischer 2008).

\section{Szárazföldi közlekedési folyosók}

A szárazföldi közlekedési folyosókat az euroázsiai közlekedési kapcsolatokról szóló 2000 májusában megrendezett genfi konferencián Németország, Oroszország és az Európai Bizottság képviselői, valamint az ENSZ Európai Gazdasági Bizottsága (UNECE), az ENSZ Ázsiai Gazdasági és Társadalmi Bizottsága (UNESCAP) és a Vasutak Nemzetközi Szövetsége (UIC) javasolták, és 2000 szeptemberében hivatalosan is elfogadták a II. Nemzetközi Eurázsiai Közlekedési Konferencián kiadott deklarációjukban Szentpéterváron (Transport links between Europe and Asia 2006).

A két kontinens közti szárazföldi összeköttetések kereséséhez több tényező együttes fennállása vezetett. Egyrészt, ahogy a fentiekben láttuk, a tengeri szállítás rendkívül időigényes. A szárazföldi szállítás ezzel szemben lényegesen rövidebb útvonalon bonyolódik (hossza $20000 \mathrm{~km}$ helyett $12000 \mathrm{~km}$ ), tehát lényegesen gyorsabb, mint a tengeri szállítás. A Nyugat-Európa és Kína közötti szállítási idő így 18-22 napra rövidülhet, ami a szállítandó áruk növekvő értékét figyelembe véve nem elhanyagolható a gazdasági szereplők szempontjából (Ivanova-Toikka- 
Hilmola 2006). A szárazföldi szállításnak egyébként is vannak hagyományai a két kontinens között. Gondolhatunk itt az egykori Selyemútra, de a kelet-európai rendszerváltás előtt is jelentős mennyiségű áru jutott el vasúton Kínából NyugatEurópába. Az utóbbi másfél évtizedben ez a forgalom gyakorlatilag megszünt, illetve a tengeri szállítás olcsóbbá válása miatt szinte teljes egészében tengeri útvonalra terelődött. A jövőben azonban az emelkedő olajárak és a növekvő biztonsági kockázatok a tengeri fuvarozási ráták emelkedéséhez, ezzel együtt pedig a szárazföldi szállítási módok részarányának növekedéséhez vezethetnek. A szárazföldi folyosók újra felértékelődését eredményezte az is, hogy az európai kikötők forgalma, ezen belül is leginkább a konténerforgalom az elmúlt időszakban dinamikusan növekedett, és ez a tendencia a jövőben erősödni látszik. A tengeri forgalom gyors növekedésének további akadályait jelenti a csatornák és szorosok korlátozott átbocsátóképessége, a kikötők vízoldali infrastruktúrájának (vízmélység és dokkok kapacitása) és szárazföldi megközelítésének hiányosságai. Mindezen tényezők világossá tették, hogy a két kontinens közti szállítási szükségleteket a jövőben nem lehet pusztán a kikötői és tengerhajózási kapacitások növelése által kielégíteni (Fleischer 2008).

\section{1. ÁBRA}

Az eurázsiai szárazföldi közlekedési folyosók

(The Eurasian Land Transport Corridors)

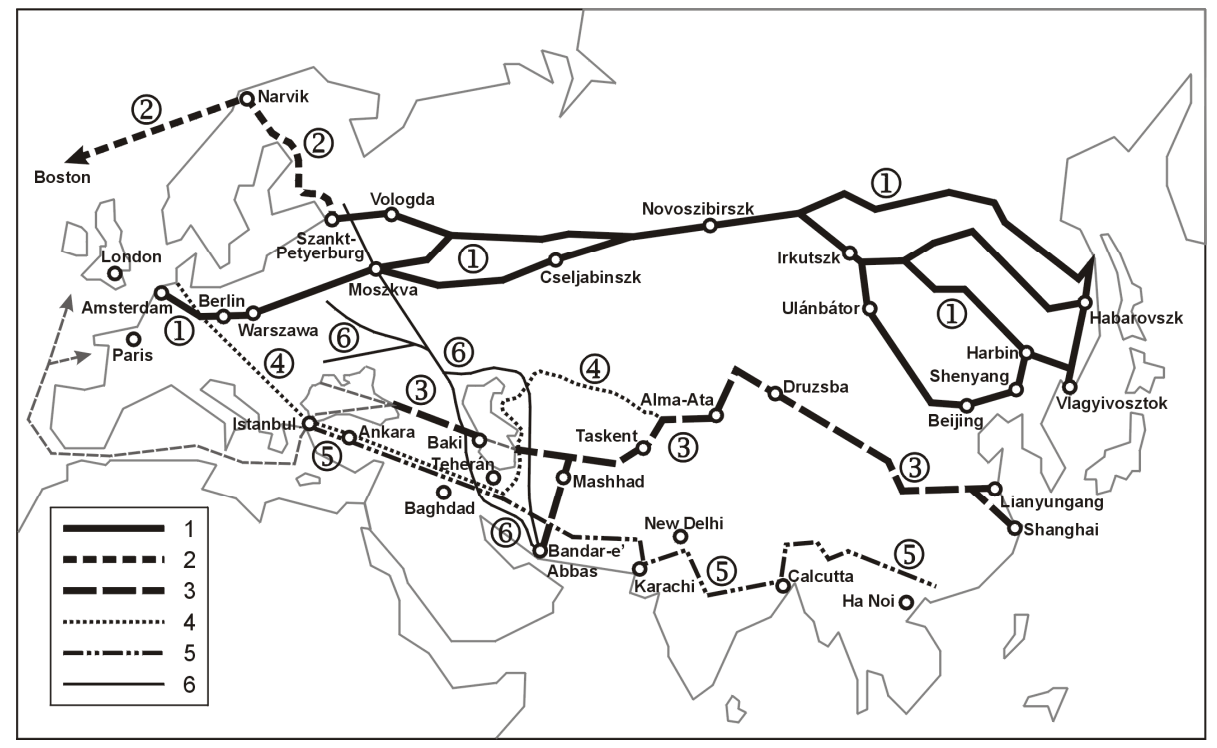

Jelmagyarázat: 1: Transzszibériai vasút; 2: N.E.W. korridor; 3: TRACECA korridor; 4: előbbi kiegészítései; 5: déli szárazföldi korridor; 6: észak-déli korridor.

Forrás: Erdősi $(2009,90)$. 
2000 szeptemberében az alábbi Európát Ázsiával összekötő szárazföldi útvonalak kerültek elfogadásra (1. ábra):

- Az ábrán 1 jelü, transzszibériai korridor egy Moszkvát és Vlagyivosztokot összekötő létező kapcsolat a volt Szovjetunió területén egységes széles vágánnyal, amely mind Észak-Európa (Szentpétervár), mind Nyugat-Európa (Varsó-Berlin), mind Közép- és Dél-Európa felé is bejáratott folytatással rendelkezik. A vasútvonal az Orosz Föderációban három ágra szakad: Kazahsztánon, illetve Mongólián keresztül Kína felé és a Koreai-félsziget felé jelent összeköttetést. A transzszibériai folyosó egy időben a két kontinens közti konténerforgalom 11\%-át is szállította, a mai nagyobb forgalomból a részesedése jóval kisebb, de az utóbbi időben dinamikusan növekszik: az 1998-2007 közötti időszakban megkilencszereződött a rajta bonyolódó konténerforgalom. Az orosz állam 2015-ig komoly beruházásokat ( 2 milliárd USD) tervez a hálózaton, 40 millió USD-t már be is fektettek az orosz-kínai határon az infrastruktúra fejlesztésébe. Ezen túlmenően 2030-ig 6700 km új pályaszakasz építését is célul tüzték ki (Lukov 2008).

- A 3 jelü, TRACECA nemzetközi közlekedési folyosó kifejezetten politikai indíttatásból jött létre, tényleges hagyománya nincs. A Szovjetunió szétbomlása után, 1993 májusában az Európai Unió konferenciát szervezett a közép-ázsiai országok vezetői számára, ahol Transport Corridor Europe-Caucasus-Asia néven javasolt egy útvonalat, amely egyfelöl elkerüli Oroszországot, másfelöl felfüzi a nyolc ázsiai és kaukázusi FÁK-országot (Örményország, Grúzia, Azerbajdzsán, Kazahsztán, Üzbegisztán, Türkmenisztán, Kirgizisztán, Tadzsikisztán), és végeredményben Kína felé teremt összeköttetést. Az útvonal elsősorban közút, Constanzából indul és több páneurópai folyosóhoz (IV, VII, VIII, IX) is kapcsolódhat. A TRACECA azonban mind müszaki, mind politikai szempontból problémás útvonal, ezért nem tekinthető versenyképes alternatívának. A projektben részt vevő országok többsége politikailag instabil, egyes országok között regionális konfliktusok is vannak, ezen kívül a kaukázusi szakasz vasúti hálózata komoly beruházásokat igényel, és a kikötői átrakó kapacitásokat is modernizálni kell. (Az ábrán a 4 jel a TRACECA folyosó európai folytatásait jelöli.)

- Az ábrán 5 jelü, déli nemzetközi közlekedési folyosó az Oroszországot elkerülő hagyományos vasútvonalakon alapszik. Hátránya, hogy négy, különböző nyomtáv alkotja, valamint, hogy az egymással is konfliktusban álló Indián, Pakisztánon, Iránon, Irakon és Törökországon keresztül érkezik Európába.

- A 6 jelű, észak-déli nemzetközi közlekedési folyosó: a Balti-tenger és a Perzsaöböl között alkot szárazföldi hidat, ezzel a hajózás számára elhagyhatóvá téve mind Afrika, mind Európa megkerülését. Az 1. ábra 2 jelzéssel feltünteti a déli folyosó szárazföldi meghosszabbítását, amely elérve Narvik kikötőjét már Észak-Amerika felé jelenthet további kapcsolatot (Transport links between Europe and Asia 2006; Ivanova-Toikka-Hilmola 2006; Fleischer 2008; United Nations 2008).

A transzszibériai vasútvonal tehát a négy 2000-ben kijelölt eurázsiai szárazföldi közlekedési útvonal közül az egyetlen müködőképes összeköttetés, napjainkban ezen keresztül bonyolódik az EU és a FÁK-térség, illetve az EU és Kína közötti 
vasúti áruszállítás döntő része. A Moszkva-Kijev-Budapest vasútvonalon elhelyezkedő Záhony és a magyar-ukrán határtérség a transzszibériai folyosó Közép- és Dél-Európa felé történő meghosszabbításaként tud bekapcsolódni az Európa és Ázsia közti vasúti áruszállításba.

\section{Az EU-Kina és az EU-FÁK-térség közti kereskedelmi kapcsolatok tendenciái}

Az utóbbi évtizedben a délkelet-ázsiai térség és Kína, valamint a FÁK-térség (különösen Oroszország) gazdasági növekedése messze meghaladta a világgazdaság más (fejlett) régióinak fejlődési ütemét. Az ENSZ világgazdasági helyzetről készített legfrissebb jelentése szerint a 2000-2008 közötti időszakban a huszonhét tagú Európai Unió reál GDP-növekedése átlagosan csupán 2,2\%-os volt, míg a FÁKtérség és a délkelet-ázsiai országok 7\% feletti, Kína pedig ennél is nagyobb mértékü, 9,6\%-os gazdasági növekedést produkált (United Nations 2010).

A régió országaiban megfigyelhető gazdasági fellendülés a kereskedelmi kapcsolatokra is ösztönzőleg hatott: az EU és a régió országai közötti kereskedelmi forgalom az elmúlt évek során rendkívüli mértékben megnövekedett. Az Eurostat adatai szerint például az EU és Kína közötti teljes kereskedelmi forgalom 1999 és 2008 között 4,5-szeresére (72 milliárd euróról 326 milliárd euróra), az EU és a FÁKtérség közti szállítások összege pedig ennél is nagyobb mértékben, több mint ötszörösére (70 milliárd euróról 375,8 milliárd euróra) emelkedett. Az előrejelzések szerint a két kontinens közti kereskedelmi kapcsolatokban az ezredforduló óta tapasztalható fellendülés akár 15-20 éven keresztül is folytatódhat. A szállítások összetételét vizsgálva megállapítható, hogy 2008-ban a Kínából származó uniós behozatal túlnyomó részét gépek és szállítóeszközök, illetve különféle feldolgozóipari termékek alkották, és az EU exportjában is ezek a termékcsoportok domináltak. A FÁKtérségből érkező import ezzel szemben elsősorban ásványi fütőanyagokat tartalmazott, de az uniós kivitelt illetően ebben a relációban is a gépek és szállítóeszközök, illetve a különféle feldolgozóipari és vegyipari termékek aránya volt jelentős.

Az EU és a FÁK-térség, illetve Kína közötti kereskedelmi kapcsolatok élénkülése a szállitási ágazattal szemben is folyamatos és megnövekedett igényeket támaszt. Ugyanakkor, mivel a forgalomnövekedés nemcsak a FÁK-országokból Európába irányuló exportban kulcsszerepet játszó energiaszállításokat jellemzi, hanem érinti a nyersanyagok, a félkésztermékek, sőt az ázsiai termeléskihelyezések révén a feldolgozóipari és magas hozzáadott értékü termékek kereskedelmét is, diverzifikált és az elörejelzések szerint egyre növekvő keresletet, ezzel együtt azonban komoly logisztikai kényszereket is jelent a nemzetközi közlekedés számára. 


\section{A vasút szerepe az EU-Kina és az EU-FÁK-térség közti áruszállitásban}

Az Európai Unió harmadik országokkal folytatott kereskedelmében a földrajzi meghatározottságoknak köszönhetően föként a tengeri szállítás a meghatározó. 2006-ban az EU-n kívülre szállított export 76\%-a (0,5 milliárd tonna) bonyolódott tengeri úton, az EU-n kívüli importnak pedig 69\%-a (1,8 milliárd tonna) érkezett hajón. A csővezetékek részaránya elsősorban az importban volt magas (16\%), míg a közúti szállítások az EU-n kívülre irányuló exportban képviseltek ugyanekkora részarányt. A vasút az exportszállítások 5\%-ának, az importszállítások 4\%-ának lebonyolításáért volt felelös.

A szárazföldi szállítás érthető módon az európai partnerek esetében dominál. A vasúti szállítás az egykori szovjet tagköztársaságok esetében a közúti szállítási módnál is nagyobb részarányt képvisel, míg az EFTA-országok és az egyéb európai országok (CEFTA, Törökország) esetében kevésbé jelentős. A 2006-os adatok alapján a vasúti szállítás a távolabbi földrajzi régiókkal (így a Kelet- és Dél-Ázsiával folytatott árukereskedelemben) egyelőre nem játszik fontos szerepet (Panorama of Transport 2009).

Az Eurostat adatai szerint az EU és a FÁK-térség közti szállítások 2008-ban 49,2\%ban tengeri úton, 6\%-ban közúton bonyolódtak. A vasút a szállított mennyiség 12,5\%-ának célba juttatásáért volt felelős. Az 1999-es adatokkal összehasonlítva elmondható, hogy az utóbbi évtizedben a tengeri és a közúti szállítási mód részaránya nőtt jelentősen. A vasúton szállított árumennyiség ugyan 28,8\%-kal nőtt 1999 és 2008 között, azonban a vasút részaránya az összes szállításokon belül 16\%-ról 12,5\%-ra csökkent (1. táblázat).

\section{TÁBLÁZAT}

Az EU27 és a FÁK-térség közötti áruforgalom megoszlása szállitási módok szerint

(Trade in Goods between the EU27 and the CIS by Modes of Transportation)

\begin{tabular}{|c|c|c|c|c|}
\hline \multirow[b]{2}{*}{ Szállitási módok } & \multicolumn{2}{|c|}{1999} & \multicolumn{2}{|c|}{2008} \\
\hline & $\begin{array}{l}\text { millió } \\
\text { tonna }\end{array}$ & $\begin{array}{c}\text { részesedés } \\
(\%)\end{array}$ & $\begin{array}{l}\text { millió } \\
\text { tonna }\end{array}$ & $\begin{array}{c}\text { részesedés } \\
(\%)\end{array}$ \\
\hline Tengeri szállítás & 120,4 & 34,9 & 280,4 & 49,2 \\
\hline Vasúti szállítás & 55,5 & 16,0 & 71,4 & 12,5 \\
\hline Közúti szállítás & 16,5 & 4,8 & 34,6 & 6,0 \\
\hline $\begin{array}{l}\text { Egyéb (csővezetékes, } \\
\text { légi és ismeretlen } \\
\text { eredetü) }\end{array}$ & 152,3 & 44,3 & 184,1 & 32,3 \\
\hline Összesen & 344,7 & 100 & 570,5 & 100 \\
\hline
\end{tabular}

Forrás: az Eurostat adatai alapján saját számítások. 
Az EU és Kína közötti szállítások 2008-ban döntően (89,8\%) tengeri úton bonyolódtak. Közúton az összes árumennyiség 4,3\%-át, míg vasúton csupán $0,6 \%$-át szállították. 1999 és 2008 között ebben a relációban is elsősorban a tengeri szállítások részaránya nőtt, a közúti és a vasúti szállítási mód részaránya csökkent (a közúté 3\%-kal, a vasúti 0,3\%-kal). A részarány-csökkenés azonban mindkét esetben a szállított árumennyiségek megduplázódása mellett történt (2. táblázat).

2. TÁBLÁZAT

Az EU27 és Kina közötti áruforgalom megoszlása szállitási módok szerint (Trade in Goods between the EU27 and China by Modes of Transportation)

\begin{tabular}{|c|c|c|c|c|}
\hline \multirow[b]{2}{*}{ Szállítási módok } & \multicolumn{2}{|c|}{1999} & \multicolumn{2}{|c|}{2008} \\
\hline & $\begin{array}{l}\text { millió } \\
\text { tonna }\end{array}$ & $\begin{array}{c}\text { részesedés } \\
(\%)\end{array}$ & $\begin{array}{l}\text { millió } \\
\text { tonna }\end{array}$ & $\begin{array}{c}\text { részesedés } \\
(\%)\end{array}$ \\
\hline Tengeri szállítás & 23,6 & 82,6 & 83,9 & 89,9 \\
\hline Vasúti szállítás & 0,2 & 1,0 & 0,5 & 0,7 \\
\hline Közúti szállítás & 2,1 & 7,4 & 4,1 & 4,4 \\
\hline $\begin{array}{l}\text { Egyéb (csővezetékes, } \\
\text { légi és ismeretlen } \\
\text { eredetü) }\end{array}$ & 2,6 & 9,0 & 4,7 & 5,0 \\
\hline Összesen & 28,6 & 100 & 93,3 & 100 \\
\hline
\end{tabular}

Forrás: Eurostat adatai alapján saját számítás.

A közút és a vasút tengeri útvonalakkal szembeni térnyerését elsősorban a tengeri szállítás versenyképes árai korlátozzák: nem következett be ugyanis a tengeri fuvarozási ráták korábban előrejelzett emelkedése, sőt 2005 és 2009 második negyedéve között az Európa és Ázsia közti szállítások vonatkozásában egy TEU szállítása 9\%-kal, az Ázsia és Európa közti szállítások vonatkozásában pedig 50\%-kal csökkent $^{3}$ (United Nations 2009). Egyelőre az európai kikötők is képesek a megnövekedett szállítási igények kiszolgálására: az Európai Tengeri Kikötők Szervezetének 2007. évi jelentése szerint Rotterdam 11,4\%, Hamburg 11,6\%, Antwerpen 16,5\%, a keletmediterrán és fekete-tengeri kikötők pedig 13\%-kal tudták növelni konténerforgalmukat az előző évhez képest (ESPO Annual Report 2008).

\section{A záhonyi vasúti áruforgalom tendenciái a rendszerváltás után}

Záhony 1945-ig egy kisforgalmú, néhány vágánnyal rendelkező vasútállomás volt, a vasúti forgalom nagy része a szomszédos Csap állomáson bonyolódott. A második világháború után azonban a magyar-szovjet gazdasági kapcsolatok fellendülése szükségessé tette egy olyan vasúti csomópont kiépítését, ahol lehetséges a széles nyomtávolságú vasúton érkező áruk normál nyomtávra történő átrakása. Az átrakókörzet építése és fejlesztése 1946-ban kezdődött és egészen a kilencvenes évekig tartott, és ennek eredményeképpen Záhony egy $120 \mathrm{~km}^{2}$ kiterjedésü, $315 \mathrm{~km}$ normál és 157 km szélesnyomtávú vágányhálózattal rendelkező, két normál- és két 
széles nyomtávú rendező-pályaudvart, továbbá számos speciális vasútüzemi és logisztikai funkciót ellátó, két határátmenettel rendelkező vasútüzemi körzetté fejlődött.

A nyolcvanas évek végéig az átrakókörzet fejlesztését a folyamatosan növekvő mennyiségi igény vezérelte. A Záhonyban átrakott áru legdinamikusabb mennyiségi növekedése a hatvanas évekre tehetö, és ez a tendencia egészen 1987-ig folytatódott: ekkor érte el az átrakókörzet tényleges teljesítményének eddigi csúcsát 5,1 millió tonnás kilépő és 12 millió tonnás belépő forgalommal. Ebben az időszakban különösen jövedelmezőnek bizonyult a MÁV számára a tranzitforgalom, amely a nyolcvanas évekre kb. 2 millió tonna belépő és kb. 1 millió tonna kilépő árumennyiséget jelentett (Fleischer 1999).

A kilencvenes évek folyamán a külkereskedelmi kapcsolatok átorientálódása a záhonyi vasúti áruforgalom fokozatos csökkenéséhez vezetett. Az átrakott áru mennyisége 1998-ban érte el mélypontját 1 millió tonnás kilépő és 3,9 millió tonnás belépő forgalommal, amely az 1987-ben átrakott eddigi legnagyobb mennyiség 28,5\%-a (2.,3. ábra). Az évtized végére a tranzitforgalom is jelentősen lecsökkent: mind a belépő, mind a kilépő tranzit a korábbi mennyiség hatodára esett vissza.

\section{2. ÁBRA}

Záhony vasúti áruszállitási összforgalma (1990-2008)

(The Volume of Rail Freight Traffic at Záhony [1990-2008])

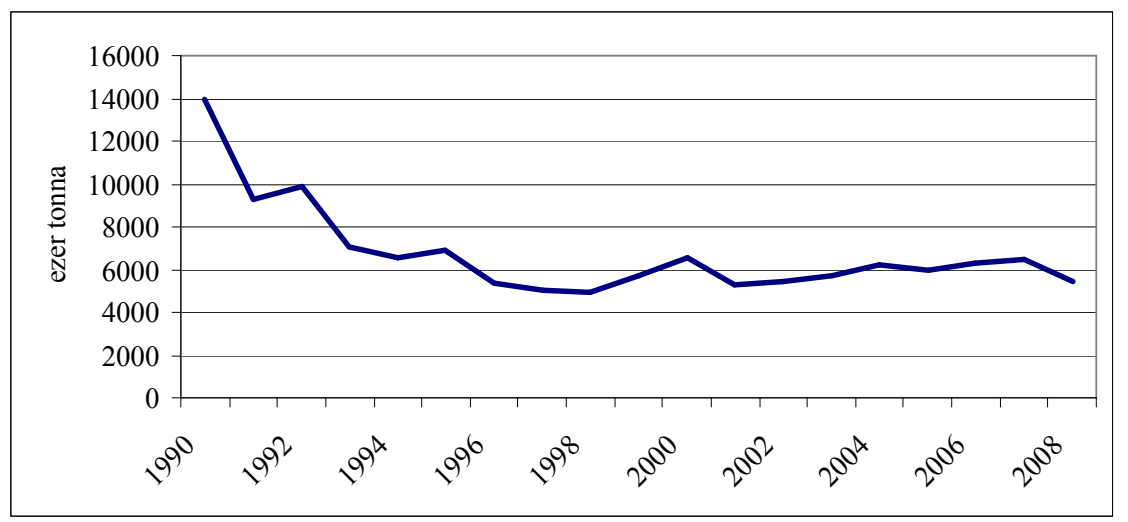

Forrás: MávCargo adatai alapján a szerző szerkesztése.

A MÁV Cargo adatai szerint az ezredforduló utáni időszakban a Záhonynál átrakott, kelet felől (elsősorban a Független Államok Közösségéből és a balti országokból) érkező árumennyiség több mint 90\%-a továbbra is döntően Magyarországra irányult, és a kelet felé kilépő árumennyiség is körülbelül ilyen részarányban tartalmazott magyarországi szállításokat. A FÁK-ból Magyarországra irányuló szállításokban a nyersanyagok és alacsony feldolgozottságú termékek dominálnak. 2007-ben a legnagyobb részarányt a különböző ércek (elsősorban vasérc), a kőszén, a mütrágya, a fekete fémek és a cement képviselték, míg a gépek, berendezések részaránya elenyésző volt. Az importszállítások elsősorban Fejér, Szabolcs-Szatmár-Bereg, Hajdú-Bihar és Borsod-Abaúj-Zemplén megyébe irányultak. A Szabolcs-SzatmárBereg megyei forgalom nagy részét maga a Záhonyi Logisztikai Térség dolgozta 
fel, a Fejér megyei forgalmat a Dunai Vasmü ércszállítmányai jelentették, míg a Borsod-Abaúj-Zemplén megyei forgalom nagy részét a Tiszai és a Borsodi Vegyi Kombinátba irányuló alapanyag szállítmányok alkották. A Magyarországról FÁK-ba irányuló vasúti szállítások döntő többségükben élelmiszereket (elsősorban konzerveket), illetve gabonaféléket tartalmaztak ${ }^{4}$.

\section{3. ÁBRA}

A belépö és kilépö vasúti áruforgalom alakulása Záhonynál (1990-2008)

(The Incoming and Outgoing Rail Freight Traffic at Záhony [1990-2008])

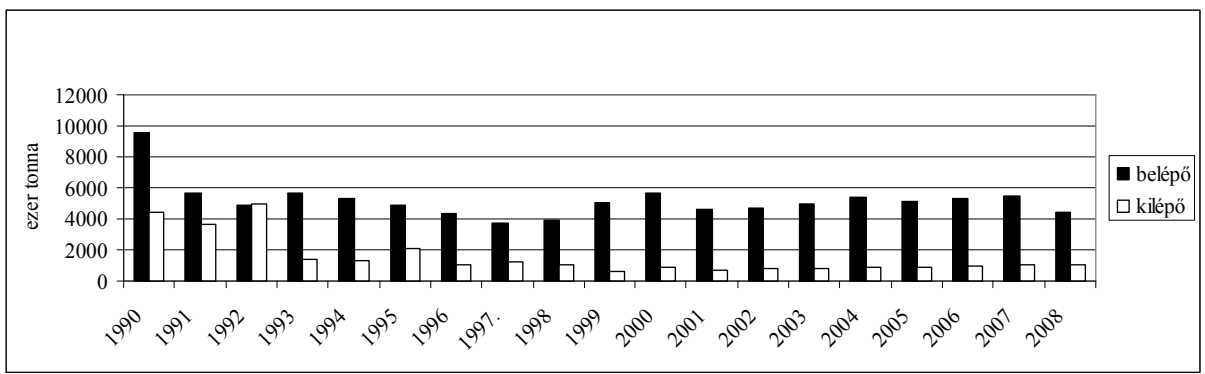

Forrás: MávCargo adatai alapján a szerző szerkesztése.

A tranzitforgalomnak nemcsak a mennyisége csökkent a rendszerváltás után, hanem jelentős volt az irány szerinti átrendeződés is. A tranzitforgalmat az ezredforduló után egyértelmüen a FÁK és Ausztria közötti szállítások dominanciája jellemezte. A 2007-es adatok némiképp kiegyenlítettebb megoszlást mutatnak a tranzitirányok között: a kétirányú, teljes tranzitforgalom 37,3\%-a Ausztria és a FÁKtérség, 30\%-a Horvátország, Szerbia, Szlovénia és a FÁK-térség, 32,4\%-a pedig harmadik ország és a FÁK-térség között bonyolódott. 2008-ban amellett, hogy a kelet felé irányuló tranzitszállítások a válság hatására harmadukra estek vissza, nőtt a Szerbiába, Szlovéniába, Horvátországba irányuló szállítások részaránya 5 .

Megállapíthatjuk, hogy a záhonyi átrakó központ számára jövedelmező tranzitirányok közül csak egy, a FÁK-térség és Szerbia közötti áruszállítás szorul rá biztosan a magyarországi közlekedési folyosó igénybevételére. A FÁK-térség és Ausztria, Szlovénia, illetve Horvátország közötti vasúti szállítmányok esetében a Magyarországon keresztül történő szállítás csak az egyik lehetőség az áru megrendelőhöz történő eljuttatására: Záhony ezekben a tranzit-relációkban versenyben áll a szlovákiai Čierna nad Tisou (Ágcsernyő) átrakó állomással.

2008-ban új reláció jelent meg a Máv Cargo statisztikáiban az import- és a kelet felől érkező tranzitszállítások esetében: a harmadik országból Magyarországra érkező, illetve Nyugat-Európa felé áthaladó forgalom volumene egyelőre kevésbé jelentős (összesen 20,6 ezer tonna), hosszú távon azonban az elemzők többsége az árumennyiség növekedésével számol. A szállítások hátterében a GYSEV Zrt. és a szállítmányozóként közremüködő Far East Landbrige Ltd. megállapodása állhat, akik 2012-ig közösen kívánják müködtetni a Kína és Nyugat-Európa közötti vasúti teherszállítási útvonal magyarországi szakaszát. Az első kínai konténervonat 2008 januárjában érkezett Záhonyba, 2009. márciustól pedig megindultak a rendszeres szállítások is ${ }^{6}$. 


\section{A záhonyi átrakó körzet versenytársai}

A normál és a széles nyomtávrendszert elválasztó államhatárvonal az Oroszországhoz tartozó Kalinyingrádi Körzettől a Duna-deltáig tart. Ezen a nyomtávhatáron több mint egy tucat átrakókörzet (illetve határátmenet) müködik (5. ábra), tehát Záhony nincs monopolhelyzetben a kelet-nyugati irányú vasúti áruforgalom lebonyolítását illetően (Fleischer 2007).

\section{4. ÁBRA}

A széles és normál nyomtávú hálózat közti átrakó állomások és övezetek (Transshipment Yards and Zones between the Standard and Broad Gauge Networks)

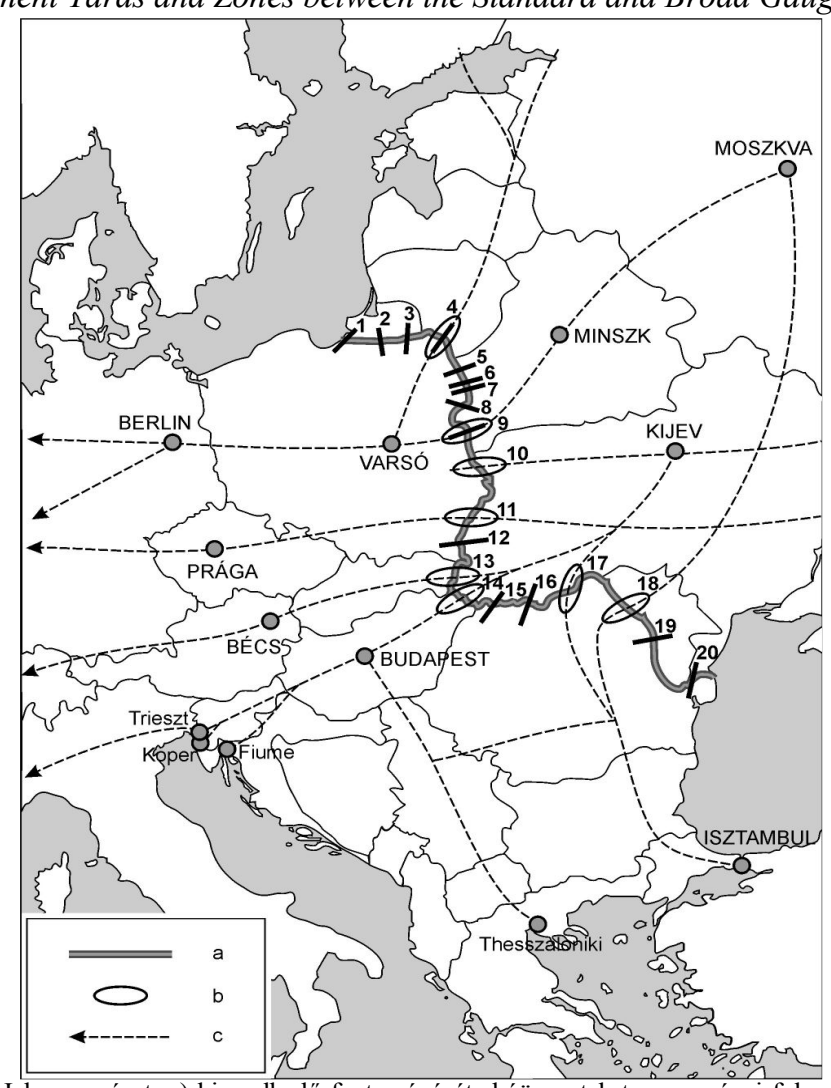

Jelmagyarázat: a) kiemelkedő fontosságú átrakóövezetek transzeurópai folyosókon; b) egyéb nemzetközi határátmenetek; c) a legnagyobb átrakóövezeteken áramló forgalom fö irányai; 1 Mamonovo-Braniewo; 2 BagriationovszkBartoszyce; 3 Zseleznodorozsnyi-Skandawa; 4 Seštokai-Trakiszki; 5 LososnyaKuznyica-B; 6 Bol Beresztovica-Zubki Bialostockie; 7 Svislocs-Siemianowka; 8 Viszoko Litovszk; 9 Breszt-Terespol/Malaszewicze; 10 Jagodin-Dorohusk; 11 Mosztiszka-Medyka; 12 Chirov-Kroscienko L.; 13 Csap-Tiszacsernyö; 14 Csap-Záhony; 15 Korolevo-Halmeau; 16 Jasinya Valea-Viseului; 17 Vadul Sire-Vicşani; 18 Iasi-Ungeni; 19 Succeova-Pascani; 20 Buzau-GalatiReni-Benderi.

Forrás: Erdősi $(2009,81)$. 
A széles nyomtávú hálózat területével a leghosszabb érintkezési vonala és egyúttal legtöbb határátmenete a közép-kelet-európai normál nyomtávú térségen belül Lengyelországnak van, mely északkeleten és keleten négy széles nyomtávú országgal határos. Jelentőségében, a forgalom méreteiben valamennyi határátmenet közül a Varsó-Minszk-Moszkva korridorvonal melletti Malaszewicze emelkedik ki, ennek megfelelően a nyomtávkülönbség legyőzésére szolgáló infrastruktúra is itt a legfejlettebb, ezért az áruk határon való átjuttatása itt igényli a legkevesebb időt. Ezen a határátmeneten bonyolódnak a FÁK-térség (elsősorban Oroszország) és Németország közötti szállítások (Erdösi 2009).

Szlovákia egyetlen átrakóállomása Čierna nad Tisou, amelyen keresztül áramlik a Közép-Európa (Ausztria, Csehország) és a FÁK-államok közötti tranzit egy része is. A széles nyomtávú pályaszakasz azonban Mat'ovcénél át is szeli a szlovák határt és mintegy 88 km hosszan, egészen Kassáig kiépült. Ezt a pályaszakaszt arra használják, hogy a kassai acélhengermü számára átrakás nélkül lehessen vasércet szállítani. A 2007-es adatok alapján a Kelet-Szlovákiai Átrakó Telep (Čierna nad Tisou és Mat'ovce) által kezelt áruk 73\%-át a vasércszállítmányok tették ki, az egyéb áruk (fa, metanol, ömlesztett áru) csupán az átrakott mennyiség 27\%-át jelentették (ZSSK Cargo Business 2008, 6).

Magyarország húsz kilométernél is hosszabb átrakó körzete (a Budapest-LvovKijev-Moszkva vonalon) Komorónál kezdődik és Záhonyig tart, míg a túloldalon Csoptól folytatódik néhány kilométeres mélységben. Az 1970-80-as évek fordulóján néhány évig ez volt a legforgalmasabb átrakókörzet a Szovjetunió nyugati határán, de többnyire Malaszewicze után a második helyet foglalta el. A záhonyi logisztikai és átrakó központ számára a legkomolyabb konkurrenciát jelenleg a tőle mindössze 5-6 km-re fekvő szlovákiai Čierna nad Tisou jelenti. A rendszerváltás előtt a szlovákiai átrakó övezet forgalma nem volt Záhonyéhoz mérhető, elhanyagolható szerepet töltött be a kelet-nyugati irányú vasúti áruforgalom lebonyolításában (Erdősi 2009). A kilencvenes években végrehajtott beruházásoknak, a rugalmasabb ügyintézésnek és árpolitikának köszönhetően azonban napjainkra a korábbi záhonyi vasúti forgalom egy része (elsősorban a FÁK-térségből a balkáni országokba és Ausztriába irányuló szállítások esetén) a határ szlovák oldalára terelődött. A ZSSK Cargo adatai alapján ${ }^{7}$ a 2005-2008 közötti időszakban évente átlagosan mintegy 16-17\%-kal több árut raktak át a szlovákiai Čiernán, mint Záhonyban. Čierna versenyelőnye elsősorban a FÁK-térségből érkező import és tranzitszállítások esetében érvényesült, míg a kelet felé irányuló export és tranzit esetén Záhony domináns pozíciója vitathatatlan. (5., 6. ábra; az 5. ábra mutatja a szlovákiai Mat'ovcénél átrakás nélkül be- és kilépő árumennyiséget is, amely azonban jellegénél fogva nem jelent konkurrenciát Záhony számára.) 


\section{5. ÁBRA}

A Szlovákiába és Magyarországra keleti irányból vasúti úton érkezö import és tranzit (2005-2008)

(The Import and Transit Goods Entering Slovakia and Hungary by Rail from the East, 2005-2008)

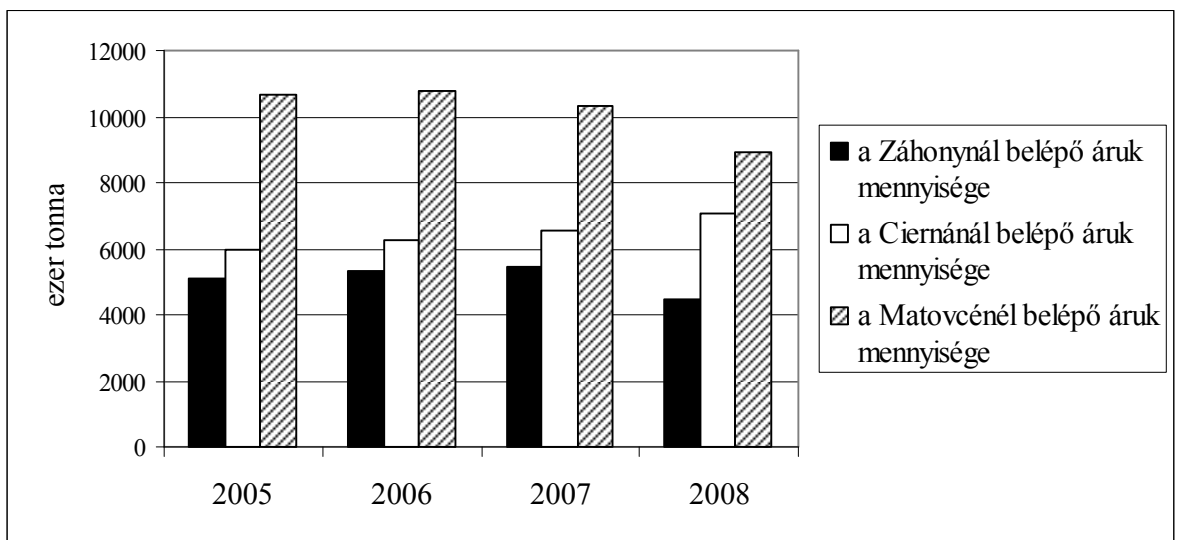

Forrás: MávCargo, ZSSK Cargo adatai alapján a szerző szerkesztése.

6. ÁBRA

A Szlovákiából és Magyarországról keleti irányba vasúton kilépö export és tranzit (2005-2008)

(The Export and Transit Goods Leaving Slovakia and Hungary by Rail toward the East, 2005-2008)

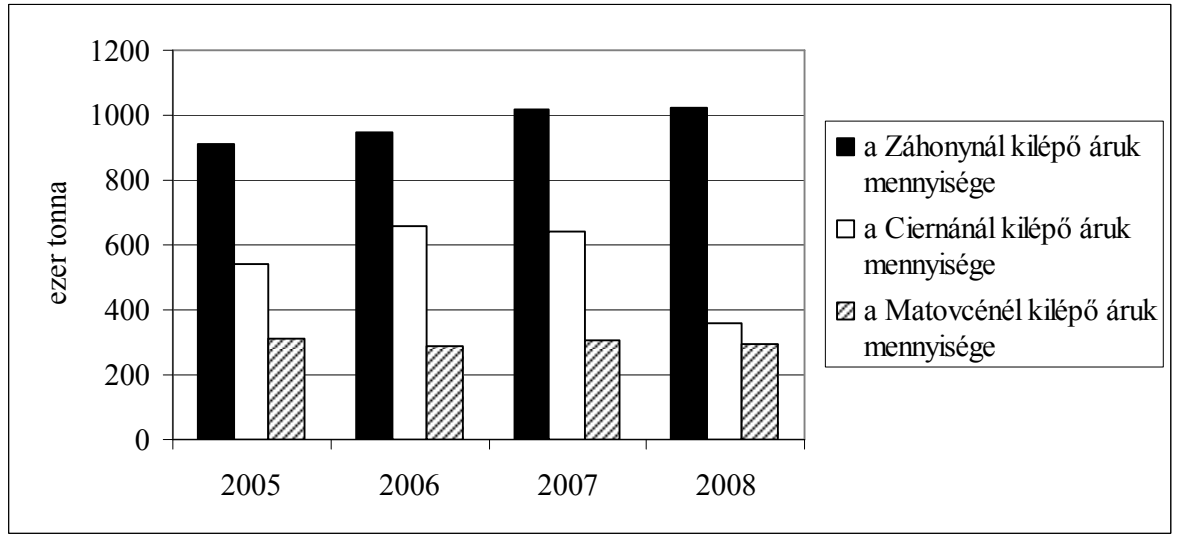

Forrás: MávCargo, ZSSK Cargo adatai alapján a szerző szerkesztése.

A konkurrens vasúti útirányokhoz kapcsolódva érdemes említést tenni arról is, hogy az elsősorban vasúti szempontból kiépített Záhony számára konkurenciát jelent minden, a vasúttal versenyben álló ágazat is, mindenekelőtt a közút. Kérdés tehát, hogy a jövőben milyen mértékben folytatódik a távolsági áruforgalom közútra terelődése, az érintett országok ezt kifejezetten elősegítik-e, vagy pedig vasúti és 
kombinált szállitási formák igényes kínálatával és más módon fékezni próbálják (Fleischer 1999). 2007-ben mintegy 240000 kamion, azaz 3-3,5 millió tonna áru lépte át a határt Záhonynál, tehát körülbelül a vasúton szállított mennyiség fele érkezett közúton Magyarországra. A közúti szállítások esetében domináns a tranzit, szemben a vasúti szállitásokkal. Szabolcs-Szatmár-Bereg megyén belül azonban Záhonyon kívül több közúti határátkelöhely is müködik Ukrajna felé (Lónya, Barabás, Beregsurány és Tiszabecs), amelyek teherforgalmáról nem álltak rendelkezésünkre adatok.

A 2007-2013-as időszakra elkészített Magyar Logisztikai Stratégia készítői Záhony logisztikai csomópont szerepe szempontjából komoly veszélynek látják, hogy egy 2006 tavaszi döntés értelmében az M3-as autópálya, amely a Lvivet Magyarországon és Szlovénián keresztül Trieszttel és Velencével összekötő V. számú transzeurópai folyosó részét képezi, Barabás és Beregdéda között lépi majd át a határt, és a Záhonycsapi határállomás csak gyorsforgalmi úttal kapcsolódik a sztrádához. Záhony logisztikai csomópont szerepének megőrzése érdekében javasolják, hogy a metszéspont ne Barabásnál, hanem Záhonynál legyen (Magyar Logisztikai Stratégia 2007-2013 2008). Ez a felvetés annak fényében különösen megfontolandó, hogy 2011-re a szlovák-ukrán határon is új nemzetközi közúti határátkelő megnyitását tervezik Čierna és az ukrán Solomonovo között, amely 11 km-re helyezkedne el a Dobrán található kombinált szállítási termináltól.

\section{Összegzés}

A záhonyi vasúti áruforgalom mértékére vonatkozóan nem (vagy csak nagyon áttételesen) lehet következtetéseket levonni az EU-Kína, illetve az EU-FÁK-térség közti kereskedelmi forgalom-növekedésböl.

Noha az elmúlt évtizedben a vasúton szállított áruk mennyisége mindkét reláció esetében növekedett, a vasúti szállítási mód részaránya az összes szállított árumenynyiséghez viszonyítva azonban csökkent. Az áruszállitás továbbra is mindkét relációban döntően tengeri úton bonyolódik.

Az Eurostat adatai alapján az EU és FÁK-térség, illetve EU és Kína viszonylatában kimutatott vasúti áruforgalomnövekedés hatással volt ugyan a transzszibériai vasút konténerforgalmára, viszont nem vagy alig volt érzékelhető a záhonyi átrakó körzet viszonylatában, amelynek konténerforgalma továbbra is elenyésző (1\% alatti). Ennek valószínủ oka az, hogy a kelet-nyugati irányú vasúti áruforgalom döntő része a Moszkva-Minszk-Varsó korridorvonal mentén fekvő és Nyugat-Európa felé összeköttetést jelentő lengyel átrakó körzeteken (különösen Breszt-Malaszewicze határállomáson) keresztül bonyolódik.

A záhonyi átrakó körzet és logisztikai központ jövőbeli fejlödése szempontjából véleményünk szerint a következő tényezők lesznek meghatározóak:

- Mivel a Záhonynál vasúton belépö árumennyiséget jelenleg is elsősorban a FÁK-térség és Magyarország közti kereskedelmi kapcsolatok határozzák meg, 
a záhonyi projektet igazán az ipari-logisztikai területre betelepülö, keleti nyersanyagot feldolgozó, termelő nagy- és középvállalkozások tehetik sikeressé. (Ilyen jelenleg az ERDÉRT Rt., amely tuzséri telephelyén müködteti az ország egyik legnagyobb fafeldolgozó üzemét, amelyhez az alapanyagokat elsősorban a határon túlról, Ukrajnából és Oroszországból importálja, vagy a Taurus Carbonpack Kereskedelmi és Szolgáltató Kft., amely a francia Michelin-csoport tagjaként a keleti piacokról érkező gumiipari alapanyagok kezelésével, csomagolásával foglalkozik.) Biztató, hogy komplex gazdaságfejlesztési program megvalósításának kezdete óta újabb külföldi tulajdonú vállalatok érdeklődtek a térség iránt, így például az ukrajnai Vorskla Steel Fényeslitkén valósít meg acélhengermüvi beruházást 650 millió euróból.

- A keleti piacok (mindenekelőtt Ukrajna és Oroszország) fejlődése. E két ország gazdasági stabilizációja a Délkelet-Európa és a FÁK-országok közötti tranzit árumozgás fellendülését vonhatja maga után, amelynek bizonyos hányada a záhonyi térség közúti, illetve vasúti folyosóin haladhat keresztül, felértékelve a határtérség logisztikai, raktározási szerepkörét.

A tranzitszállítások tekintetében ugyan a szlovákiai Čierna nad Tisou elhelyezkedésével és vasúti kapcsolataival valódi versenytársa Záhonynak, azonban területe, hálózati kapcsolata és mai, illetve tervezett kiépítettsége miatt lényegesen hátrányosabb helyzetben van, mint Záhony. Mindezek ellenére az elmúlt években megindult a vasúti áruforgalom átterelődése a határ szlovák oldalára. Tanulságként megállapítható, hogy a záhonyi átrakó központ és logisztikai térség vonzerejét nem csak az ottani létesítmények és szolgáltatások színvonala, hanem az odavezető vasúti pályadíjak, illetve az ottani rakodási díjak nagysága és a megvalósítási idő is erősen befolyásolja. Ebből következik, hogy a projekt müködtetése csak akkor lehet rentábilis, ha ezen díjak mértéke olyan lesz, ami versenyképes összárakat tud a fuvaroztatók számára nyújtani annak érdekében, hogy Záhonyt válasszák a vetélytársakkal szemben. Tehát egy összehangolt, a teljes szállítási láncra kiterjedő árajánlatot kell kialakítani, amihez szükséges az állam szerepvállalása is, elsősorban szabályozási oldalról.

A szlovákiai átrakóközpont közelsége és hálózati kapcsolatrendszere azonban a versenyhelyzet mellett egyúttal lehetőséget is kínálhat az együttmüködésre, a közös konszenzuson alapuló összehangolt fejlesztésre is az V. folyosó adottságainak jobb kihasználására érdekében.

- A kínai tranzit jelentőségét a záhonyi átrakó körzettel kapcsolatban ma még nehéz megítélni. 2009. évben megindultak a rendszeres szállítások Kína és NyugatEurópa között Záhonyon keresztül, azonban a vasúti szállítás tengeri szállítással szembeni térnyerését korlátozzák a tengeri szállítások versenyképes árai. A komplex gazdaságfejlesztési programhoz készített áruforgalmi prognózis készítői szerint a Záhonyon keresztül történő vasúti szállítás elsősorban a Kína belső területén előállított és/vagy relatíve értékes áruk esetében lehet alternatíva, ahol számít a fuvarozási idő, illetve azoknál az áruknál, ahol a célpont közép-európai ország. 


\section{Jegyzetek}

${ }^{1}$ Hivatkozik rá: Kálnoki Kis Sándor Záhony - Strategic position in the new Europe címü előadásában.

${ }^{2}$ A komplex gazdaságfejlesztési program keretében 2009 áprilisában indultak meg az építkezések a térségben és ezzel megkezdődött az Új Magyarország Fejlesztési Terv egyik kiemelt beruházásának a megvalósítása. A programról bővebben: www.zahonyprogram.hu.

${ }^{3}$ TEU (Twenty-foot Equivalent Unit, azaz Húsz lábbal egyenértékủ egység): az a szabványosított egység, amely a 20 láb $(6,10 \mathrm{~m})$ hosszúságú ISO konténer adatain alapszik, és amelyet a forgalmi áramlás vagy kapacitás statisztikai méröszámaként alkalmaznak. Egy standard 40' ISO 1. sorozatú konténer 2 TEU-val egyenértékủ. A 20 láb alatti csereszekrények 0,75 TEU-nak, a 20 és 40 láb közöttiek 1,5 TEU-nak, a 40 láb felettiek pedig 2,25 TEU-nak felelnek meg.

${ }^{4}$ A MávCargo 2007 és 2008. évi forgalomegyeztetési jegyzőkönyvei alapján.

${ }^{5}$ A MávCargo 2007 és 2008. évi forgalomegyeztetési jegyzőkönyvei alapján.

${ }^{6}$ A vállalkozásról bővebben: www.fareastlandbridge.com.

7 Železnična spoločnost' Cargo Slovakia (2005) Statistical Yearbook. Železnična spoločnost' Cargo Slovakia (2006) Statistical Yearbook. Železnična spoločnost' Cargo Slovakia (2007) Statistical Yearbook. Železnična spoločnost' Cargo Slovakia (2008) Statistical Yearbook.

http://www.zscargo.sk/en/public/press/annual-report (letöltés ideje: 2010. március 22.)

\section{Irodalom}

Ad Toet (2005) 'Wider Europe'TEN-T Public Consultation on extension of TEN-axis. (powerpoint előadás) http://ec.europa.eu/ten/transport/external_dimension/hlg/2005_03_31_tent_consultation/doc/stakeholders_pre sentations/02_wider_europe_cer.pdf (letöltés ideje: 2010. március 22.)

Erdősi F. (2007) A politika szerepe a Balkán közlekedésében. - Glatz F (szerk.) A Balkán és Magyarország. Magyarország az Ezredfordulón. Stratégiai tanulmányok a Magyar Tudományos Akadémián. MTA Társadalomkutató Központ - Európa Intézet, Budapest. 343-355. o.

Erdősi F. (2009) Kelet-Európa közlekedése. Dialóg Campus Kiadó, Budapest-Pécs.

ESPO Annual Report 2007-2008. (2008) European Sea Ports Organisation, Brussels. http://www.espo.be/downloads/archive/8bfl fded-66f6-4e0f-8204-7e52754b9b69.pdf (letöltés ideje: 2010. március 22.)

Fleischer T. (1999) A záhonyi régió közlekedési helyzetelemzése, jövőképe, összhangban térségi és nemzetközi szerepével. MTA Világgazdasági Kutatóintézet, Budapest.

Fleischer T (2007) Logisztika - trendek és mítoszok: Környezettudatos meggondolások a magyarországi logisztikai rendszer-elképzelésekről. - Közlekedéstudományi Szemle. 2. 51-57. o.

Fleischer T. (2008) A távol-keleti kapcsolatok logisztikája és a Duna lehetséges szerepe. Mühelytanulmányok 78. MTA Világgazdasági Kutatóintézet, Budapest.

Ivanova, O.-Toikka, T.-Hilmola, O. (2006) Eurasian container transport market: Current status and future development trends with consideration of different transport modes. Lappeenranta University of Technology, Department of Industrial Engineering and Management, Kouvola Research Unit, Research Report $179 \mathrm{http}: /$ /kouvola.lut.fi/files/download/Research_Report_179_Nora.pdf. (letöltés ideje: 2010. március 22.)

Lukov, B.E. (2008) Transsiberian Rail Corridor - Present Situation and future prospects. (powerpoint előadás) Promit seminar: Connecting Europe and Asia with Transsiberian Rail. http://www.promitproject.net/UploadedFiles/Events/Pres_Seminar_7thWorkshop/Lukov_CCTT_TSR.pdf. (letöltés ideje: 2010. március 22.)

Magyar Logisztikai Stratégia 2007-2013. (2008) munkaanyag http://www.ngm.gov.hu/ data/cms1821957/MLSNFGM_finalframe_080704.pdf (letöltés ideje: 2010. március 22.)

Panorama of Transport (2009) Eurostat Statistical Books. Luxembourg, European Communities. http://epp.eurostat.ec.europa.eu/cache/ITY_OFFPUB/KS-DA-09-001/EN/KS-DA-09-001-EN.PDF. (letöltés ideje: 2010. március 22.) 
Transport links between Europe and Asia. (2006) European Conference of Ministers of Transport. http://www.internationaltransportforum.org/europe/ecmt/pubpdf/06Europe-Asia.pdf. (letöltés ideje: 2010. március 22.)

United Nations (2008) Joint study on developing Euro-Asian transport linkages. United Nations, New York and Geneva. http://www.unece.org/trans/main/eatl/in house study.pdf. (letöltés ideje: 2010. március 22.)

United Nations (2009) Review of Maritime Transport. United Nations Conference on Trade and Development, United Nations, New York-Geneva. http:/www.unctad.org/en/docs/rmt2009_en.pdf. (letöltés ideje: 2010. március 22.)

United Nations (2010) World Economic Situation and Prospects. United Nations, New York. http://www.un.org/esa/policy/wess/wesp2010files/wesp2010.pdf. (letöltés ideje: 2010. március 22.)

ZSSK Cargo Business (2008) ZSSK Cargo Slovakia, 2. http:/www.zscargo.sk/files/Cargobusiness/CARGO-BUSINESS-2-screen.pdf (letöltés ideje: 2010. március 22.) 